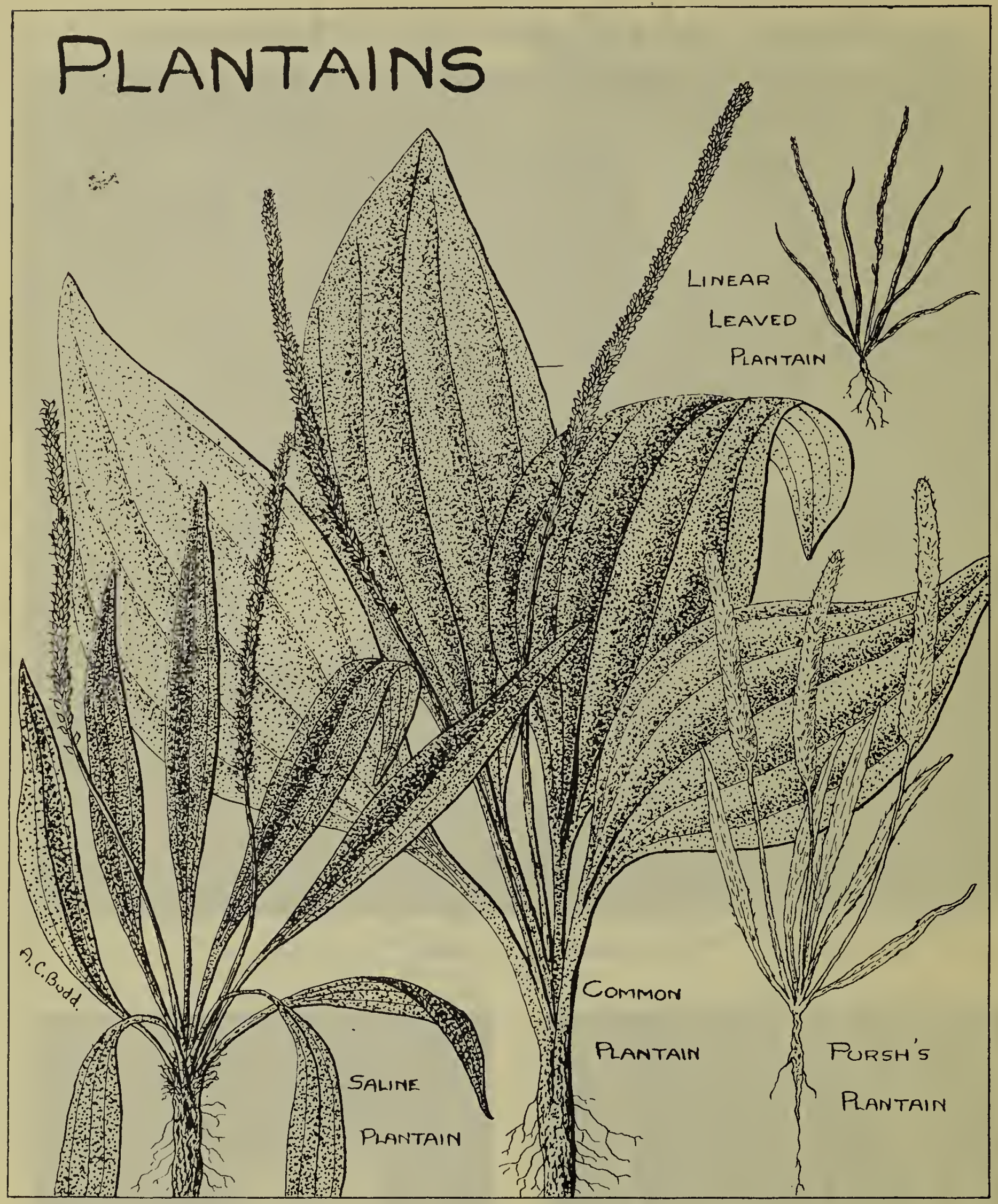

\title{
The Plantains of Saskatchewan
}

\section{By ARCHIE BUDD}

The Plantains or Ribworts are a genus of plants found in most parts of the world and there are thought to be more than 250 separate species. The scientific name of Plantago applied to this genus means "footprint" from the shape of the leaf of the commonest species, Plantago major $L$. This is the Common or English Plantain, which has been carried by the white races to almost every parts of the globe, and is often called "whiteman's foot" by the coloured races. Plantains are characterized by longitudinally ribbed leaves, very minute whitish flowers borne on long rat-tail like spikes, and by the leaves and flowering stems all arising from the crown of the root. The fruit are small capsules and at maturity the top falls off, releasing the several tiny seeds. This type of fruit is 
called a pyxis, meaning a box.

In Saskatchewan we find six species, four of which are fairly plentiful; one is quite rare and the other one found, but not persisting, on newly seeded lawns sown to eastern or far western grass seed.

A simple key to determine the Saskatchewan species is as follows:

1. Leaves linear to thread-like-2. Leaves lanceolate to ovate-4.

2. Leaves densely whitish, silkywoolly - Plantago Purshii; Leaves green and hairless-3.

3. Inflorescence with bracts at least twice as long as the flowersPlantago spinulosa; Inflorescence with bracts less than twice length of the flowers-Plantago elongata.

4. Leaves ovate, not tapering to stalk-Plantago major; Leaves lanceolate, tapering to stalk-Plantago eriopoda.

Plantago major or Common Plantain is the species found in waste areas, roadsides and gardens almost everywhere and becomes quite a weed in places. The Saline Plantain $(P$. eriopoda) generally has a mass of brownish hairs at the crown of the root and is fairly plentiful around moist saline areas, creek banks and so on. Pursh's Plantain (P. Purshii) is a whitish, very silky-woolly species found plentifully on sandy and light soils, especially in the south-western part of the province. A very small, insignificant species, Linear-leaved Plantain ( $P$. elongata) is occasionally to be found along muddy slough margins and is easily mistaken for Mouse-tail (Myosurus) at first sight. A very scarce species is the Bracted Plantain ( $P$. spinulosa) which has been occasionally found in dry areas and has bracts below the flowers from a quarter to three-eighths of an inch long.

Economically the plantains are considered of negligible value, but birds are fond or the fruit and the spikes of Common Plantain are often fed to cage birds. The leaves of Common Plantain rubbed on misquito bites seem to relieve the discomfort. Pursh's Plantain is grazed a little by sheep but the food value is limited, and it is reported that the young leaves of Common Plantain were used as food by the Indians of New Mexico.

\title{
Familiar Wild Flowers
}

\author{
By B. DE VRIES, Fort Qu'Appelle
}

\section{No. 2 Western Red Lily}

\section{Lilium philadelphicum}

\section{L. var. andinum (Nutt.) Ker}

The Western Red Lily, a variety of the Wood Lily (L. philadelphicum L.), is a typical of the Liliaceae (Lily Family), a family of Monocotyledons. Both the Western Red Lily and the Wood Lily are perennial herbs growing from white scaly bulbs to height of about 20 inches. The difference between the two species is in the leaves. The Western Red Lily has alternate lower leaves and the upper ones in whorls while the Wood Lily has all its leaves in whorls. Venation in both species is parallel-linear. Flowers are hermaphrodite and regular, with parts in threes. The perianth is petaloid, occupying the two outer whorls, and followed by two whorls of stamens with a superior ovary of three carpels; the ovary is three chambered with a number of axile placentas. The fruit is a capsule splitting along the septa and containing many seeds. Because the Western Red Lily belongs to the Lily Family, with the parts in threes, we can write down

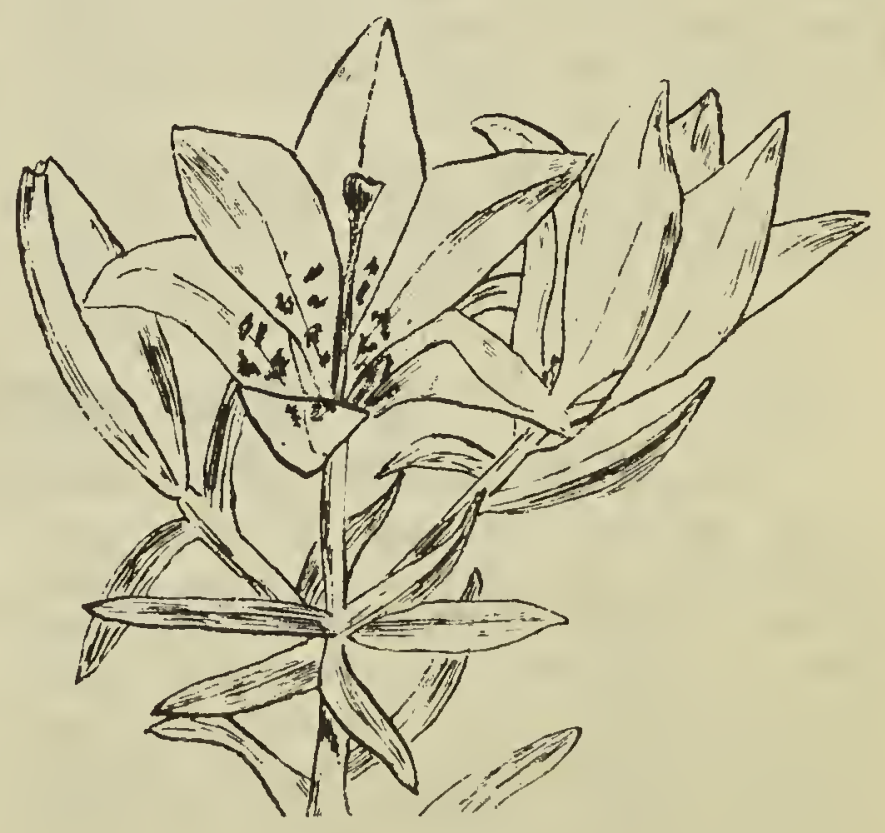

